\title{
EFFECT OF STEVIA LEAVES CONSUMPTION ON SUGAR AND OTHER BLOOD CHARACTERS IN DIABETES-INDUCED MICE
}

\author{
H. M. S. Al-Hamdani, \\ Assist. Prof. \\ Market Research \& Consumer Protection Center/Baghdad Univercity / Iraq \\ Cioffi16@yahoo.com
}

\begin{abstract}
This study was designed to confirm the effect of different concentrations of water extract for stevia leaves on lowering blood sugar, cholesterol and other blood traits in diabetes-induced mice. Forty mice with weights ranging 30-35 mg per diabetic were injected intravenously into the gastric tube except for control group (nondiabetic control) and were left for one week to confirm their diabetes. The animals were divided randomly into 5 groups with 8 mice per group; animals were given in group 1 (non-diabetic control) and group 2 (diabetic control) fed standard diet with water supply, while groups 3,4 and 5 were fed standard diet and different concentrations 300, 400 and $500 \mathrm{mg}$ / dl / day respectively of aqueous extract of stevia leaf powder for a period of three weeks. A significant reduction was found in blood sugar, cholesterol, total fat and equal levels of other blood traits in groups 3 and 4 compared to group 2. The results also showed that giving the aqueous extract of Stevia at a concentration of 300 and $400 \mathrm{mg} / \mathrm{kg}$ weight, the blood sugar level is statistically and directly reduced in all treated diabetes-induced groups of mice. It also led to a statistical reduction of cholesterol and triglyceride. There is also a statistically significant increase in other blood characters in diabetic mice was also found that leaves of the stevia plant contained 7,86, 5,28 and $2,58 \%$ for both steviol glycoside, stevioside and rebaudoside respectively that measured by HPLC technique. These results have shown that consumption the leaves extract of stevia plant have an important role in reduction blood sugar, cholesterol and total fat, as well as other blood traits in mice induced for diabetes.
\end{abstract}

KEYWORDS: Steviol glycoside, stevioside, blood glucose, stevia extract

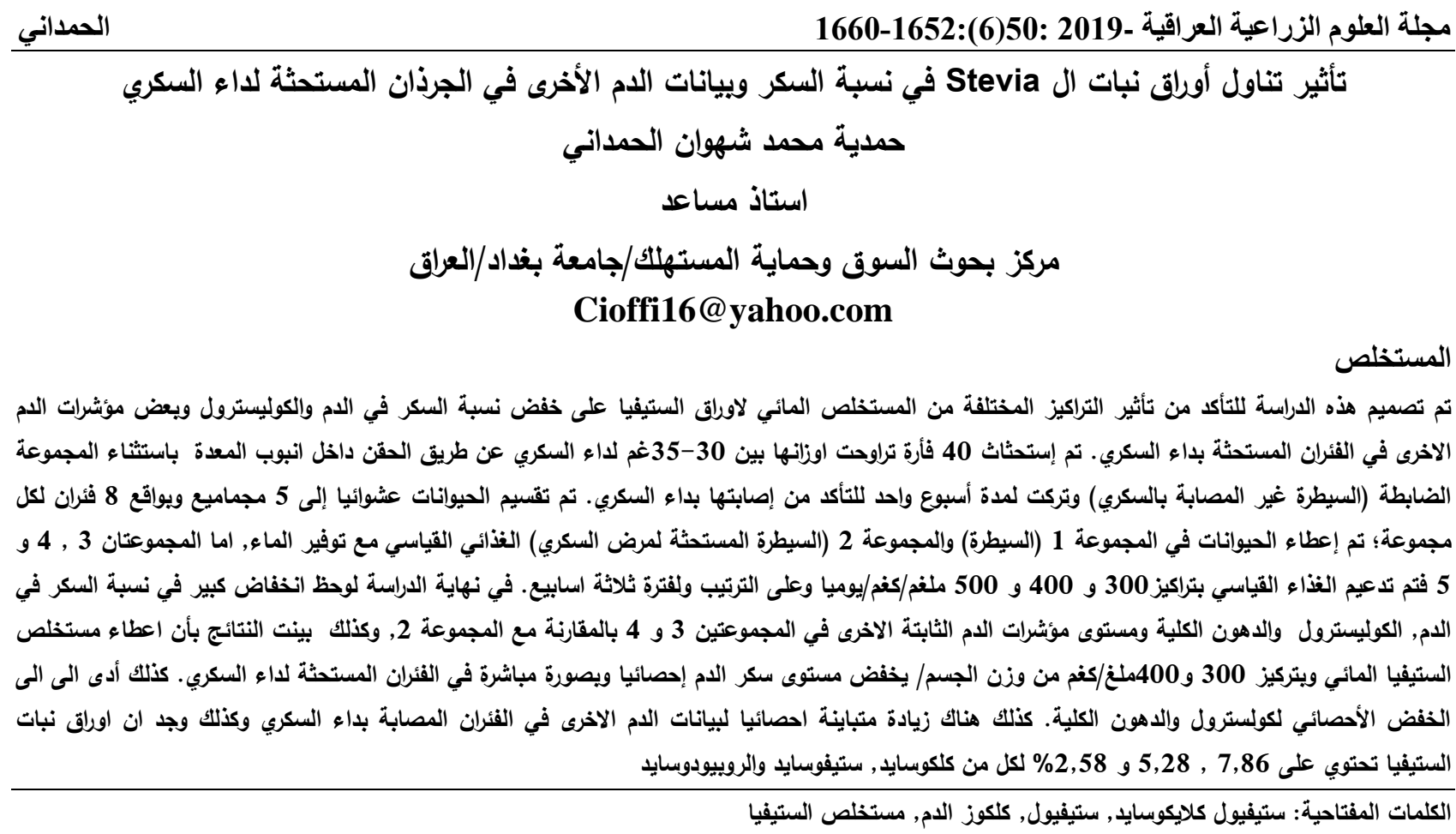




\section{INTRODUCTION}

Diabetes is a major issue in the present century for the steady increase of diabetics in most developed and developing countries of the world $(39 ; 44)$. In addition, diabetes, if not treated quickly, will be followed by many chronic diseases, such as insulin resistance, which in turn lead to many complications including coronary heart disease, hypertension, renal failure, serum lipid distortion, arterial failure, renal failure and high body fat. S0 that diabetes presented as a common chronic disorder of carbohydrates and leading cause of high percentage death in the world which needs constant care and attention (41). Diabetes treatment can be decreased by various by consuming healthy diet, exercise and pharmacologic therapy. There are a lot of chemical drugs that have proven to be able to maintain blood sugar levels but there are many side complications, which have not yet been proven to be safe for use (25). In addition, there is often a lot of uncertainty about these drugs used to treat diabetes that may be carcinogenic, so many scientists advise and prefer the use of effective herbal plants, including Stevia rebaudiana bertoni for the treatment of diabetes because of its low cost, effectiveness as antioxidants oxidation and minor side effects. Intensive studies have been conducted since 2006 to date, and through the collection of various sources on the studies of the characteristics of the plant and its chemical and food components (4), which have been fully protected and promise to contain any adverse effects of their use as a domestic or therapeutic by the World Health Organization (6). Among these concerns are control of blood sugar and effects on the reproductive, cardiovascular (11), and renal systems (17, 26). The importance of the stevia's plant is attributed in the food industry to its content the diterpene glycosides, stevioside and rebaudioside A (RebA) that's gives the sweettasting (10). In addition to being a non-caloric sweetener known in many parts of the world, it has antioxidant and antihypertensive action (40). Therefore, the dietary components of stevia powder and its effect on blood sugar and fat were studied and analyzed for a group of mice induced for diabetes by (42). Furthermore the dose effectiveness dependency of stevia on morphology of the liver and pancreas as well as lipid and glycemic parameters was evaluated. In 2006, research data compiled in the safety evaluation released by the World Health Organization found stevia is completely safe and non-toxic and no adverse effects (43). Among these concerns are controlling blood sugar and effects on the reproductive, cardiovascular, and renal systems (3). Also, stevia is important in the food and beverage industry due to its high sweetness (10). In addition, being a noncaloric sweetener known in many parts of the world, and antihypertensive action (37). Hence the present study was undertaken to analyze the nutritional composition of Stevia leaf powder and to assess its hypoglycaemic and hypolipidaemic effect diabetic induced rats. Furthermore the dose effectiveness dependency of stevia on other blood characters was evaluated.

\section{MATERIALS AND METHODS}

Stevia leaves were supplied from Medical \& Aromatic Plants Research Unit/ College of Agricultural Engineering Sciences/University of Baghdad/Iraq. The plant was identification and authenticated by Botanical Survey of Agric. College (No.BSI/ SRC/5/23/201011/Tech-1585). These stems were previously cleaned well with running tap-water, then left side until semi-drying, Then leaves of the plant were separated from the stems, then were carefully cleaned again to remove the dirt and extra genus materials, washed several times with running tap water, dried in an oven at $60^{\circ} \mathrm{C}$, then grounded into fine powder by laboratory electrical grinder and placed in a sealed polyethylene bags, and then stored in a refrigerator at $4 \pm 1{ }^{\circ} \mathrm{C}$ until it used for analysis.

\section{Stevia leaves extraction}

A certain weight of stevia leaf powder was boiled at a rate of 1: 100 weight: volume in boiled water for 30 minutes and then incubated in a water bath at $40^{\circ} \mathrm{C}$ overnight with slow and orbital shaking to obtain the aqueous extract of the stevia (21). Then the aqueous solution was centrifuged $(6000 \mathrm{~g}, 10 \mathrm{~min})$ and the insoluble precipitate was discarded. The supernatant was filtered by Whatman No.1 paper. The filter output was concentrated under low pressure and at $40^{\circ} \mathrm{C}$ by using 
rotary evaporator (Laborota 4000, Heildolph, Germany) and finally freeze-dried to get the stevia extract. Then the powder were placed in tighten sealed polyethylene bags in a refrigerator and stored at $4 \pm 1^{\circ} \mathrm{C}$ until it used for analysis.

\section{Animals care}

Fourty mice (males) with weights of 30-35 g were obtained from Al-Razi center, and placed in small micro-filter-top cages at Veterinary drug Research Center/Baghdad. The mice were left for one week to become acclimatized at $22-25{ }^{\circ} \mathrm{C}$ with a $12: 12-$ hr light:dark cycle and 60-65\% humidity, retired with rodent chow and water ad libitum. The animals had free access to food; water was given through drinking bottles. The mice were applied and cared according to the protocols under the commission of Animal Care and Use Committee for Animal Investigations. The animals were randomly divided into 5 groups of 8 mice each. After fasting for $12 \mathrm{~h}$, diabetes is induced in mice by using a single intraperitoneal injection of alloxan with a dose of $40 \mathrm{mg} / \mathrm{kg}$ body weight in $10 \mathrm{mmol} / \mathrm{l}$ sodium citrate buffer with $\mathrm{pH}=4.5$ (35) to all mice signed for diabetic (DC) except group which was assigned to be non-diabetic control group (ND-C). After 5 days of the alloxan injection, blood samples were drained from mice tail and taken for glucose analysis by glucometer (Bionime Rightest GM 300, Switzerland). Animals with a blood glucose value more than $200 \mathrm{mg} / \mathrm{dL}$ were assumed to be diabetic according to (36), and the others were excluded.

\section{Experimental design}

Eight mice in each groups were conducted for the experiment: group 1 was assigned as (nondiabetic control group); group 2 was (diabetic control group) were treated with distilled water; For the treated group, stevia leaf powder was mixed at 2, 4 and $6 \%$ level with the stock diet and fed as in Table 1. The mice diet included brown rice, oats, wheat, soy, and fish meal, calcium carbonate, yeast culture dehydrated, flax seed meal (Linseed), inulin, mono-calcium phosphate, soy oil and needed vitamins and minerals as was shown in Table 2. At the end of the experiment and after $12 \mathrm{hr}$. of fasting, the mice were given a lethal overdose of isof-lorane by inhalation to obtain the blood for analysis. The blood samples were withdrawn from the heart of the mice by a medical syringe and placed in closed test tubes and placed on pieces of ice. After that, they were centrifuged with $300 \mathrm{~g}$ for $5 \mathrm{~min}$. at $4{ }^{0} \mathrm{C}$, after that serum was separated and kept in test tubes at $-80^{\circ} \mathrm{C}$ for further analysis. Analyses were carried out at the laboratory of the Veterinary drug Research Center on the day of the blood collection. Serum glucose, triglycerides (TGs), total cholesterol, and HDL cholesterol were determined using the enzymatic method at (Al-Maghreb Lab/ Baghdad) by using an auto analyzer, selectra-2 (vital science, spankeren, Netherlands).

Table1. Design of the experiment

\begin{tabular}{|c|c|}
\hline Groups & Receiving diet \\
\hline 1-NDC & Commercial standard diet (CSD) \\
\hline 2-DC & Diabetic control group (DC) fed \\
\hline & Commercial standard diet (CSD). \\
\hline 3-T200 & $\begin{array}{l}\text { Mice treated with } 200 \mathrm{mg} / \mathrm{kg} \text { b.wt. of } \\
\text { stevia powder }\end{array}$ \\
\hline 4-T400 & $\begin{array}{l}\text { Mice treated with } 400 \mathrm{mg} / \mathrm{kg} \text { b.wt. of } \\
\text { stevia powder }\end{array}$ \\
\hline 5-T600 & $\begin{array}{l}\text { Mice treated with } 600 \mathrm{mg} / \mathrm{kg} \text { b.wt. of } \\
\text { stevia powder }\end{array}$ \\
\hline
\end{tabular}

Table 2. Determination of the chemical composition of the standard feed provided to mice.

\begin{tabular}{|l|l|}
\hline Diet compenents & $\%$ \\
\hline Moisture & 11.0 \\
Ash & $\mathbf{2 . 6}$ \\
Protein & 15.0 \\
Fat & 3.5 \\
Crude fiber & 6.5 \\
Carbohydrate & $\mathbf{6 1 . 4}$ \\
Calcium & 1.2 \\
\hline Phosphorous & $\mathbf{0 . 8}$ \\
\hline
\end{tabular}

Special Ingredients: Brown Rice, Oats and Wheat, Soy and Fish Meal

\section{Chemical composition of stevia powder}

Moisture (44-16 A), crude ash (08-07), by incineration in a muffle furnace at $580^{\circ} \mathrm{C}$ for 8hr.; fat estimated by using Soxlet extraction (30-10) were determined according to AACCapproved methods (1). The micro kjeldahl method was used for crude protein level is expressed by the total content of nitrogenous compounds multiplying the corresponding total nitrogen content by a conventional factor $\mathrm{Nx} 6.25$; dietary fiber was estimated according to (36) method; Dry matter estimated by drying in an electric oven with ventilation (JR AD/ Italy, www jradco.org) at $105^{\circ} \mathrm{C}$ until reaching constant weight $(7 ; 20)$; 
total carbohydrate was estimated by difference as shows in Table 3.

\section{Determination of blood glucose level}

Blood glucose was estimated by drawing blood from the tail vein by using the sugar test strips (Accua chek, Germany) and the examination was done daily after the administration also recorded the changes in the mice weights treated and untreated daily.

\section{Blood analysis and lipid profile}

After $21^{\text {st }}$ days of the experiment, animals were slaughtered and blood was withdrawn directly from the heart. Blood hemostasis parameters (WBC, RBC,HGB, HCT, MCV, $\mathrm{MCh}, \mathrm{MCHC}$ and PLT) were determined, the percent of total glucose, total triglycerides and cholesterol was determined using the enzymatic method in Al-Maghreb Lab, Baghdad.

The evaluation of Stevioside in Stevia leaves Stevioside concentration was measured by method $(9 ; 32)$. Filtered solution of stevia extract was injected to HPLC Agilent system. Stevioside (2000 mg/l with $95 \%$ purity) was used as the standard solution. According to the area under the Standard Peak (AUSP), stevioside concentration in the stevia leaves was determined.

\section{RESULTS AND DISCUSSION}

The proximate contents of stevia leaves are releave in Table 3 . The results showed that the plant Stevia is rich in nutrients because it contains large amounts of carbohydrate, protein, crude fiber, ash, and moisture as shown clearly in Table 3. This finding was comparable with $(2 ; 26)$. So, it can be concluded that stevia is a good source of carbohydrates, proteins, dietary fibers.

Table 3. Chemical composition of stevia leaf

\begin{tabular}{|cc|}
\multicolumn{2}{|c|}{ powder } \\
\hline Components $^{¥}$ & $\%$ \\
\hline Moisture & 4.85 \\
Ash & 9.55 \\
Protein & 11.43 \\
Fat & 4.86 \\
Crude fiber & $\mathbf{1 0 . 7 0}$ \\
\hline Carbohydrates & $\mathbf{5 8 . 1 8}$ \\
\hline
\end{tabular}

$¥=$ each value is the mean of triplicate reading

It was found that body weight significantly increased $(\mathrm{p}<0.05)$ in a diabetic groups treated $(2,3,4$ and 5) with different concentration of stevia's leaf aqueous extract when compared with control group. Rats bodies weight were treated with high dose of stevia extract increased significantly $(\mathrm{p}<0.05)$ compared with group 2 that treated with low dose of stevia powder. While, diabetic mice treated with high dose of stevia group $4 \& 5$ not significantly increased compared with nondiabetic control, group $1(\mathrm{p}<0.05)$. This finding comparable with (13). However, treated group 2 with stevia significantly decreased $(\mathrm{p}<0.05)$ the weight compared with diabetic group 2 as shows in Table 4. This finding was comparable with (38) who presented that stevia significantly decreased weight.

Table 4. Bodies weight of animals during 3 weeks of applying different concentration of

\begin{tabular}{|c|c|c|c|c|}
\hline $\begin{array}{c}1 \\
\text { N-DC } \\
\text { Control }\end{array}$ & $\begin{array}{c}2 \\
\text { DC } \\
\text { Diebete } \\
\text { control }\end{array}$ & $\begin{array}{c}3 \\
(T=300 \mathrm{mg} / \mathrm{dl})\end{array}$ & $\begin{array}{c}4 \\
(T=400 \mathrm{mg} / \mathrm{dl})\end{array}$ & $\begin{array}{c}5 \\
(\mathrm{~T}=500 \mathrm{mg} / \mathrm{dl})\end{array}$ \\
\hline 32.5 & 31.6 & 30.0 & 32.1 & 35.0 \\
\hline 30.5 & 31.5 & 29.2 & 33.1 & 39.0 \\
\hline 31.6 & 30.1 & 28.5 & 32.5 & 32.0 \\
\hline 32.5 & 31.0 & 27.8 & 32.9 & 33.1 \\
\hline 31.0 & 31.6 & 30.0 & 32.0 & 35.0 \\
\hline 33.0 & 30.0 & 30.7 & 33.0 & 34.0 \\
\hline 31.5 & 30.1 & 28.9 & 33.3 & 34.1 \\
\hline 32.0 & 20.8 & 35.1 & 34.0 & 34.5 \\
\hline$\sum 254.6$ & $\sum=236.7$ & $\sum 240.2$ & $\sum 262.9$ & $\sum 276.7$ \\
\hline $\mathrm{M}=31.8 \mathrm{~b}$ & $\mathrm{M}=29.5 \mathrm{ab}$ & $M=29.9 . a$ & $M=32.8 \mathrm{ab}$ & $M=34.5 \mathrm{ab}$ \\
\hline
\end{tabular}

Groups: 1=non-diabetic control (NDC); 2=Diabetic control DC); 3=treated with $2 \% \mathrm{mg} / \mathrm{kg}$ b.wt. with stevia extract (T); $4=$ treated with $4 \% \mathrm{mg} / \mathrm{kg}$ b.w with stevia extract $(\mathrm{T}) ; 5=$ treated with $6 \% \mathrm{mg} / \mathrm{kg} \mathrm{b.w}$ with stevia extract $(\mathrm{T})$. * $(\mathrm{P}<0.05)$.

Fasting blood sugar FBS significantly increased in all diabetic groups when compared with control mice $(\mathrm{p}<0.05)$. Surprisingly, results of this study showed a significant decrease $(\mathrm{P}<0.05)$ in the level of blood glucose compared with the control group 1 and diabetic group 2 due to the consumption of the stevia extract and all the 
different concentrations. However, 400 and $500 \mathrm{mg} / \mathrm{dl}$ of stevia extract were more effective than $300 \mathrm{mg} / \mathrm{dl}$ of stevia in lowering glucose compared with diabetic group 2 as shows clearly in Table 5. This finding was comparable with (38). The results of the study were similar to those of previous studies (33; 25 ), which showed a significant reduction in blood sugar levels in rats treated with stevioside, a glycoside extracted from the stevia plant.

Table 5. The effect of stevia extract on blood glucose of mice after three weeks.

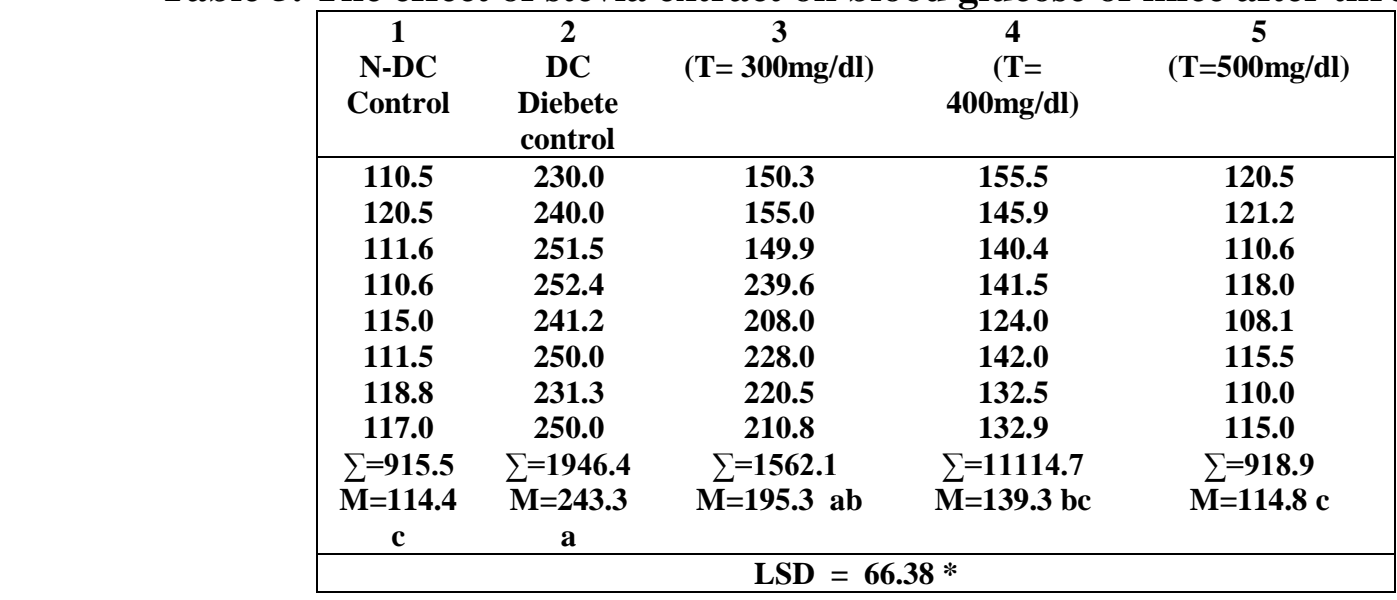

$*(\mathbf{P}<\mathbf{0 . 0 5})$.

Table 6 shows the role of different concentrations of stevia leaf aqueous extract in the maintenance of different blood parameters percentages. It was found by increasing the dose of stevia extract all blood parameters maintains or increased significantly $(\mathrm{P}<0.05)$. Overall, it seems that stevia could also decrease the amount of serum cholesterol and TG compared with diabetic group Table 6 . Similar results were observed in $(22 ; 33)$.
Previous studies have also shown the role of the stevioside component in maintaining and regulating the level of blood sugar, because of stimulation of insulin hormone in mice suffering from lack of this hormone $(29 ; 35)$. The effect of stevioide on the inhibition of gluconeogenesis due to the reduction of phosphoenol pyruvate carboxykinase (PEPCK) gene expression in liver of the rat $(12 ; 35)$.

Table 6. the changes in blood parameter in mice after three weeks of different treatments.

\begin{tabular}{|c|c|c|c|c|c|c|}
\hline \multirow[b]{2}{*}{$\begin{array}{l}\text { Hematoology } \\
\text { parameter }\end{array}$} & \multicolumn{5}{|c|}{ Different treatments of stevia extract in mice's groups } & \multirow{2}{*}{ LSD } \\
\hline & $\begin{array}{l}1 \\
\text { N-DC } \\
\text { Control }\end{array}$ & $\begin{array}{l}2 \\
\text { DC } \\
\text { Diebete } \\
\text { control }\end{array}$ & $\begin{array}{l}3 \\
(\mathrm{~T} 2 \%)\end{array}$ & $\begin{array}{l}4 \\
(\mathrm{~T} 4 \%)\end{array}$ & $\begin{array}{l}5 \\
(\mathrm{~T} 6 \%)\end{array}$ & \\
\hline $\mathrm{WBC}\left(\mathbf{x 1 0 ^ { 3 } / \mu \mathrm { l } )}\right.$ & 3.67 & 2.50 & 3.44 & 3.98 & 3.20 & $0.647 *$ \\
\hline $\mathrm{RBC}\left(\mathrm{x10}^{6} / \mu \mathrm{l}\right)$ & 3.3 & 4.7 & 4.60 & 5.24 & 4.20 & $1.09 *$ \\
\hline HGB (g/dl) & 9.88 & 8.60 & 8.33 & 9.84 & 9.50 & $1.483 \mathrm{NS}$ \\
\hline HCT (\%) & 40.6 & 55.6 & 36.0 & 38.4 & 39.00 & $7.92 *$ \\
\hline $\operatorname{MCV}$ (fl) & 85.8 & 70.5 & 75.5 & 80.9 & 82.5 & $8.47 *$ \\
\hline MCH (pg) & 17.6 & 16.2 & 16.4 & 16.6 & $\mathbf{1 7 . 5}$ & 3.37 NS \\
\hline $\operatorname{MCHC}(\mathrm{g} / \mathrm{dl})$ & 34.7 & 29.2 & 30.50 & 31.54 & 34.82 & $6.02 \mathrm{NS}$ \\
\hline PLT $\left(\times 10^{3} / \mu \mathrm{l}\right)$ & 172 & 150 & 148 & 155.7 & 166.0 & $41.49 *$ \\
\hline $\begin{array}{l}\text { Serum } \\
(\mathrm{mg} / \mathrm{dl})\end{array}$ Cholesterol & 205.0 & 218.5 & 216.1 & 210.5 & 185.5 & 33.95 NS \\
\hline Triglyceride (mg/dl) & 206.0 & 224.0 & 190.0 & 163.4 & 140.2 & $61.79 *$ \\
\hline
\end{tabular}

Globally, scientists have proved through longterm research that it is safe to eat natural stevia instead of artificial sweeteners and all age groups for humans $(36,34)$. It has been proven safe to take and use the leaves of Stevia or its extracts such as stevioside, rebaudioside A and steviol glycosides by the US Food and Drug Administration, has also been adopted as a safe food supplement for humans (Generally recognized as safe) rating in the US (GRAS Notification 287 for Steviol Glycosides with Rebaudioside A and Stevioside as Principal Components) as they indicated enough daily intake (ADI) of $25 \mathrm{mg} / \mathrm{kg}(18,5)$ (following 100 -fold safety factor, commonly seen in ADI values) in rats which is around $7.9 \mathrm{mg} / \mathrm{kg}$ in 
humans. Also, $(14,8)$ recommended that a daily intake of steviol glycoside of up to 4 $\mathrm{mg} / \mathrm{kg}$ of body weight was acceptable. The study also proved by researchers (10) that daily consumption of 500-600 mg / dl body weight from the extract of stevia leaves as a safe nutritional sweetener $(15,16)$. Currently,

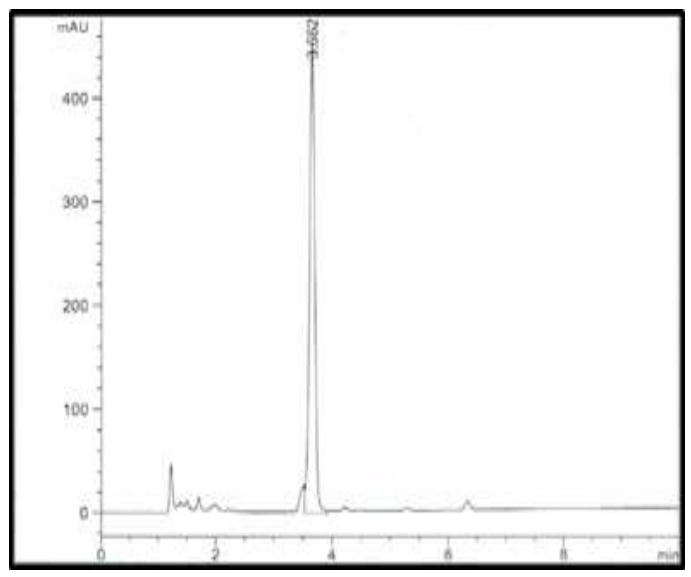

A the results of the work of the Joint Committee of Experts between the FAO/WHO Expert Committee (JECFA) on Food Additives have concluded a scientific review of all available scientific data and concluded that, stevia sweeteners are safe for use in foods and beverages $(31,39)$.

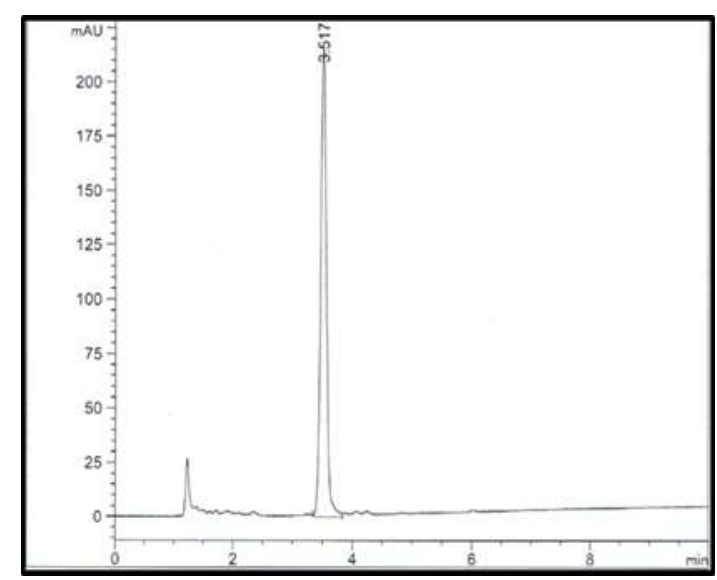

B

Results of this study showed stevioside concentration in the stevia plant leaves was 3.662 as in B was determined as in Figure 1 compared with standard 3.517 as in

Figure 1. The area under the standard peak (AUSP). Stevioside standard (A) and alcoholic extract of stevia's leaf (B).

Results of this study shows the different kinds of stevioside as in Fig. 2. It is found the highest percentage contents of stevia leaf powder was total steviol glycoside 7.86 , that's higher than finding by $(23 ; 31)$, then stevoside was 5.28 , this comparable finding with (28; 16) and rebaudoside was 2.58 , this comparable with finding by $(27 ; 28)$, while, this finding is lower than finding by $(19 ; 23)$. Jeppesen et al., (24) were showed that both steviol and stevioside can produce a direct effect on beta cells in the pancreas to release insulin, thus acts as potent antihyper-glycemic agents

\section{The percentage of St and Reb A in leaves of stevia}

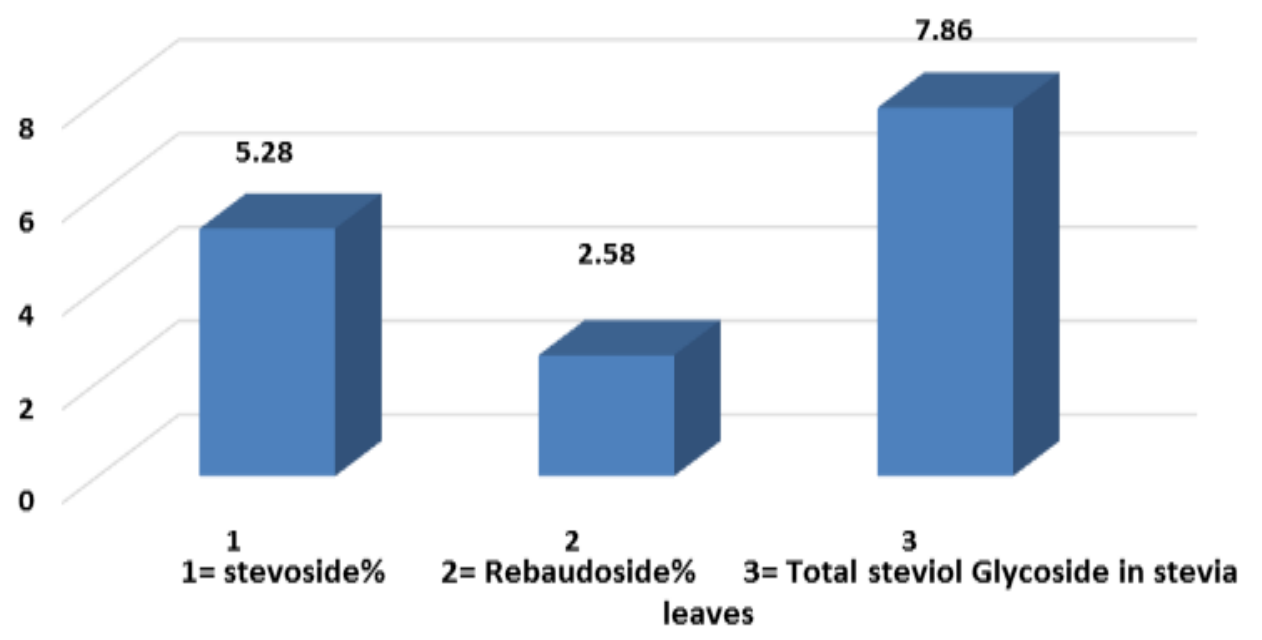

Figure 3. Shows the percentage of Stevoside, Reb A and the total steviol (St and Reb A) in stevia leaves 
Result of this study showed the effect of stevia consumption on decreasing blood glucose, cholesterol and triglyceride levels, so it can be used instead of chemical medicine to treat diabetes without any side effect. In addition, all observation during the experiment handling, it was showed mice were quiet, highly motivating activity and healthy. It can be concluded that stevia plant may be the ideal candidate for further studies and scientific research in all different scientific fields in the future. The researcher recommends many clinical trials on the real pathways of metabolism on stevia to detect and confirm many of its benefits.

\section{REFERENCES}

1. A.A.C.C. 2002. Approved Method of the American Association of Cereal Chemists Published American Association of Cereal Chemists Published Paul Minn.St.U.S.A.

2. Abou-Arab, A., and M. Abu-Salem, 2010. Physico-chemical assessment of natural sweeteners steviosides produced from Stevia rebaudiana Bertoni plant. Afr. J. Food Sci. 4: 269-281

3. Abudula, R., V. Matchkov and P. Jeppensen, 2008. Rebaudioside A directly stimulates insulin secretion from pancreatic beta cells: a glucose-dependent action via inhibition of ATP-sensitive $\mathrm{K}+$-channels. Diabetes Obes. Metab. 10: 1074-1085

4. Al-Obaidy, O. M. 2017. The roll of some plant growth regulators on shoots multiplication of stevia plants in vitro. Iraqi Journal of Agricultural Sciences, 48(5): 1158-1168

5. Alwash, B. M., 2017. Cytotoxic and antioxident activity of fruit juice of Eriobotrya japonica (Thunb.) lind plant cultivated in Iraq. The Iraqi Journal of Agricultural Sciences, 48(3): 892-898

6-Amit, K. D. 2015. Comparative study of different concentration of kinetin on shoot initiation and mass multiplication of stevia rebaudiana. European Journal of Pharmaceutical and Medical Research, 2(5): 1797-1805

7. A.O.A.C. 2005. Official Methods of Analysis of the Associatio of Analytical Chemists. 18th ed. Gaithersburg: AOAC, 2005 8. Barwary, M., K. Merkhan and E. Buti, 2019. . Evaluation of medicinal plants
(Quercus infectoria and astragalus eriocephalus) as feed additives in awassi ewe' ration. Iraqi Journal of Agricultural Sciences, 50(2): 526- 533

9. Brandle, J. and P. Telmer, 2007. Steviol glycoside biosynthesis. Phytochemistry, 68: 1855-1863

10. Carakostas, M., L. Curry and D. Brusick et al., 2008. Overview: The history, technical function and safety of rebaudioside A, a naturally occurring steviol glycoside, for use in food and beverages. Food Chem. Toxicol. 46: $1-10$

11. Chan, P., B. Linson and Y. Chen, 2000. A double blind placebo-controlled study of the effectiveness and tolerability of oral stevioside in human hypertension. Br. J. Clin. Pharmacol. 50: $215-220$

12. Chen, T., S. Chen and P. Chan, 2005. Mechanism of the hypoglycemic effect of stevioside, a glycoside of Stevia rebaudiana. Planta Med. 71: 108-113

13. Curry, L. and A. Roberts, 2008. Subchronic toxicity of rebaudioside A. Food Chem. Toxicol. 46: S11-S20

14. Ena, G., P. Shalini and S. Shanthy, 2013. Nutritional and therapeutic values of Stevia rebaudiana: A review. Journal of Medicinal Plants Research. Vol. 7(46): 3343-3353

15. Galal, K. Wafaa. 2002. Natural Stevioside Sweetener, Production, and Utilization in Food. Ph. D. D. Dissentation food technology, fac. Of Agric, Cairo Univ.

16. Gardana, C., M. Scaglianti and P. Simonetti, 2010. Evaluation of steviol and its glycosides in Stevia rebaudiana leaves and commercial sweetener by ultra high performance liquid chromatography-mass spectrometry. J. Chromatogr. A. 1217: 14631470

17. Gawel-Beben, K., T. Bujak and Z. NizilLukaszewska, 2015. Stevia rebaudiana Bert. Leaf extracts as a multifunctional source of natural, antioxidants. Molecules, 20: 54685486

18. Geuns, J. 2000. Safety of stevia and stevioside .Recent. Res. Devel., Phytochem 4: 75-88

19. Goyal, S., S. Samsher. and R. Goyal, 2010. Stevia (Stevia rebaudiana) a bio-sweetener: a review. International Journal of Food Sciences and Nutrition. 61(1): 1-10 
20. Gupta, E., S. Purwar. S. Sundaram and G. Rai, 2013. Nutritional and therapeutic values of Stevia rebaudiana: A review. Journal ofMedicinal Plants Research,7(46): 3343-3353 21. Hatter, K. 2010. How to dry Stevia leaves? (www.ehow.com/how_7253313_dry-stevia leaves).

22. Inzucchi, S., et al., 2015. Management of hyperglycemia in type 2 diabetes: A patient centered approach: Update to a position statement of the American Diabetes Association and the European Association for the Study of Diabetes. Diabetes Care 38: 140 149

23. Jaworska, K., A. Krynitsky and J. Rader, 2012. Simultaneous analysis of steviol and steviol glycosides by liquid chromatography with ultraviolet detection on a mixed-mode column: application to Stevia plant material and Stevia-containing dietary supplements. J. AOAC Int. 95: 1588-1596

24. Jeppesen, P., S. Gregersen and C. Poulsen, 2000. Stevioside acts directly on pancreatic beta cells to secrete insulin: Actions independent of cyclic adenosine monophosphate and adenosine triphosphatesensitive K+-channel activity. Metabolism 49(2): 208-214

25. Jeppenson, P., S. Gregersen and S. Rolfsen et al., 2003. Antihyperglycemic and blood pressure reducing effects of stevioside in the diabetic goto-kakizaki rat. Metabolism 52: 372-378

26. Kawshik, R., N. Pradeep and V.Vamshi, et al., 2010. Nutrient composition of cultivated stevia leaves and the influence of polyphenols and plant pigments on sensory and antioxidant properties of leaf extracts. J. Food Sci. Technol. 47:27-33

27. Kinghorn, A. and D. Soejarto, 1985. Current status of stevioside as a sweetening agent for human use, In: Economic and medicinal plant research by Wagner $\mathrm{H}$., Hikino H., Farnsworth N., (Eds.), Academic Press, London 1: 1-52

28. Kolb, N., J. Herrera and D. Ferreyra, et al., 2001. Analysis of sweet diterpene glycosides from Stevia rebaudiana: improved HPLC method. J. Agric. Food Chem. 49: 4538-4541

29. Kumar, R. 2013. Seed Germination of Stevia rebaudiana Influenced by Various
Potting Media. International peer-reviewed journal.Octa. J. Biosci. 1(2): 143-146

30. Lu, Y., Q. Zhang and j. Li, 2010. Antidiabetic effects of total flavonoids from Litsea Coreana leve on fat-fed, streptozotocininduced type 2 diabetic rats. Am. J. Chin. Med. 38(4): 713-725

31. Madan, S., G. Ahmad and K. Singh, 2010. Stevia rebaudiana (Bert.) Bertoni A Review. Indian Journal of Natural Products and Resources, 1(3): 267-286

32. Makapugay, H., N. Nanayakkara and D. D. Soejarto, 1985. High-performance liquid chromatographic analysis of the major sweet principle to Lo Han Kuo fruits. J. Agric. Food Chem. 33(3): 348-350

33. Mathur, R. and N. Johri, 2016. Nutritional composition of Stevia rebaudiana a sweet herb, and its hypoglycaemic and hypolipidaemic effect on patients with noninsulin dependent diabetes mellitus. J. Sci. Food Agric. 96: 4231-4234

34. Merkhan, K., K. Mustafa and R. Isa, 2019. Evaluation of medicinal plants (Quercus infectoria and astragalus eriocephalus) as feed additives in awassi ewe' ration. Iraqi Journal of Agricultural Sciences, 50(1): 525-115

35. Murali, R. and R. Saravanan, 2012. Antidiabetic effect of d-limonene, a monoterpene in streptozotocin-induced diabetic rats. Biomed. Prev. Nutr. 2(4): 269275

36-Nepovim, T. and V. Pavel, 2001. Determination of Stevioside in Plant Material and Fruit Teas. Journal of food composition and analysis, 14(4): 383-388

37. Pula, G., M. Milanli and S. Antonio, 2017. New seminal variety of Stevia rebaudiana: Obtaining fractions with high antioxidant potential of leaves. Anais da Academia Brasileira de Ciências, 89(3): 1841-1850

38. Raheleh, A., M. Pooneh and D. Sanaz, 2016. Hypoglycemic effect of aquatic extract of stevia in pancreas of diabetic rats: PPAR $\gamma$ dependent regulation or antioxidant Potential. Avicenna J. Med. Biotech. 8(2): 65-74

39. Savita, S., K. Sheela and S. Sharan, et al., 2004. Stevia rebaudiana - A Functional Component for Food Industry. J. Hum. Ecol.15(4): 261-264

40. Tadhani, M., V. Patel and R. Subhash, 2007. In vitro antioxidant activities of Stevia 
rebaudiana leaves and callus. J. Food Compost. Anal. 20: 323-329

41. Wild S, G. Roglic, and A. Green A. 2004. Global prevalence of diabetes estimates for the year 2000 and projections for 2030. Diabetes Care, 27(5): 1047- 1053

42. Wolwer-Rieck, U. 2012. The Leaves of Stevia rebaudiana (Bertoni), their constituents and the analyses thereof: A Review. J. Agric. Food Chem. 60: 886-895
43. World Health Organization, 2004. Diabetes: The Cost of Diabetes. http://www.who.int/mediacentre/factsheets/fs236/en/, Accessed on December 5. pp. 627-634

44-Zimmet P, K. Alberti and K., J. Shaw, 2001. Global and societal implications of the diabetes epidemic. Nature. 2001;13: 782-787 